\title{
Pleomorphic Adenoma Causing Facial Nerve Palsy
}

\author{
Kyu-Hee Han ${ }^{1}$, Ja-Won Koo ${ }^{1}$, Soon-Hyun $\mathrm{Ahn}^{1}$ and Ji-Hun Mo ${ }^{2}$ \\ ${ }^{1}$ Departments of Otorhinolaryngology-Head and Neck Surgery, Seoul National University Bundang Hospital, \\ Seoul National University College of Medicine, Seongnam; and \\ ${ }^{2}$ Department of Otorhinolaryngology-Head and Neck Surgery, Dankook University Medical College, Cheonan, Korea

\section{안면신경마비를 동반한 다형성 선종} \\ 한규희 ${ }^{1} \cdot$ 구자원 $^{1} \cdot$ 안순현 $^{1} \cdot$ 모지훈 $^{2}$ \\ 서울대학교 의과대학 분당서울대학교병원 이비인후과학교실, ${ }^{1}$ 단국대학교 의과대학 이비인후과학교실 ${ }^{2}$
}

\author{
Received July 6, 2010 \\ Revised August 17, 2010 \\ Accepted August 24, 2010 \\ Address for correspondence \\ Ji-Hun Mo, MD, PhD \\ Department of Otorhinolaryngology- \\ Head and Neck Surgery, \\ Dankook University \\ Medical College, \\ 359 Manghyang-ro, Dongnam-gu, \\ Cheonan 330-715, Korea \\ Tel $+82-41-550-3933$ \\ Fax $+82-41-556-1090$ \\ E-mail jihunmo@gmail.com
}

Facial nerve palsy due to the benign parotid tumor is extremely rare. The authors experienced a case of pleomorphic adenoma in parotid gland, showing retrograde extension to mastoid bone along the facial nerve, resulting facial nerve palsy. An 82-year-old woman with facial nerve palsy for six years was revealed to have a solid mass in the close proximity to mastoid tip with contrast enhancement on computed tomography (CT). The mass extended into the air cells of temporal bone at the exiting site of the facial nerve through stylomastoid foramen. Based on the CT findings and her facial nerve palsy, initial diagnosis was facial nerve schwannoma. Mass was removed via transmastoid approach. The pathology was pleomorphic adenoma and direct nerve invasion was not observed.

Korean J Otorhinolaryngol-Head Neck Surg 2010;53:648-51

Key Words Facial nerve $\cdot$ Adenoma Pleomorphic Schwannoma.

\section{서 론}

종양성 병변은 전체 안면신경마비를 일으키는 질환 중 약 $5 \%$ 정도를 차지한다. ${ }^{1,2)}$ 안면신경마비를 일으키는 종양 중 가장 흔한 것은 안면신경 자체에서 발생하는 안면신경초종 으로 대부분 측두골 내부의 안면신경 분절에서 발생한다. ${ }^{3)}$ 신경 주변 조직에서 발생한 종양이 안면신경을 따라 두개 내부로 진행하여 안면신경마비를 일으키는 일은 매우 드물 며, 특히 양성 종양에 의한 두개 내 침범 및 안면신경마비 는 극히 드물어 몇몇 증례로만 보고된 바 있다. ${ }^{2,45}$ 저자들 은 양성다형성선종이 경유돌공을 통해 안면신경의 수직분 절을 침범하여 마비를 일으켜 안면신경초종으로 오인된 예 를 경험하였기에 문헌고찰과 함께 보고하고자 한다.

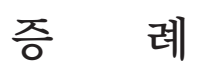

82세 여자 환자가 좌측 후이개부의 간헐적인 통증과 안면
신경마비를 주소로 내원하였다. 안면신경마비는 약 6년 전 에 발생하였으며 외래 내원 시 House-Brackmann grade $\mathrm{V}$ 로 측정되었다. 3 년 전 미용 목적의 성형수술을 받았으나 안면 비대칭에 크게 도움이 되지 않았으며, 본원 내원 시까 지 영상학적 검사를 포함한 어떠한 검사도 받아 본 적이 없 었다.

신체검사에서 안면 비대칭 이외에 특별한 소견은 없었으 나, 측두골 전산화단층촬영에서 유양 돌기와 인접하여 조영 증강되는 $1.8 \times 3 \mathrm{~cm}$ 크기의 고형 병변이 발견되었다. 이 종 물은 안면신경이 측두골에서 나오는 통로인 경유돌공을 확 장시켜며 측두골의 함기세포 내로 침범되어 있었으며, 안면 신경의 수직 분절 원위부 위치까지 연장되어 있었다 (Fig. 1). 이 병변은 자기공명영상에서 $\mathrm{T} 1$ 강조영상에서 저신호 강 도, T2 강조영상에서 고신호 강도를 보이며, gadolinium 투여 후 $\mathrm{T} 1$ 강조영상에서 조영 증강되는 소견을 보였다 (Fig. 2). 안면신경전도검사에서 반대측에 비해 $84 \%$ 정도 로 약화된 것으로 나타났으며, 미각검사는 양측 대칭적으로 
보존되어 있었다. 순음청력검사에는 경도의 고음역대 감각 신경성 난청을 보였다.

임상양상 및 영상의학적 검사에 기초하여, 안면신경종과 같은 신경원성 종양이 안면신경의 수직 분절 원위부에서 발 생하여 경유돌공을 통하여 이하선 부위까지 침범한 것으로 진단하고 수술을 계획하였다. 환자는 통증과 종양에 대한 불안감으로 수술적 제거를 원하였다. 또한 완전마비에 가까 운 안면신경마비가 수년 이상으로 오래되었기 때문에 안면 기능의 회복은 불가능하다고 판단하고 안면신경을 보존하거 나 신경 이식과 같은 안면신경 재건을 계획하지는 않았다.

수술은 경유돌접근법을 통해 시작하였다. 유양동절제술 을 시행한 후 유양돌기 첨부의 뼈를 부분적으로 제거하여 경유돌공 부분의 종양을 노출시켰다. 이하선 조직을 앞쪽

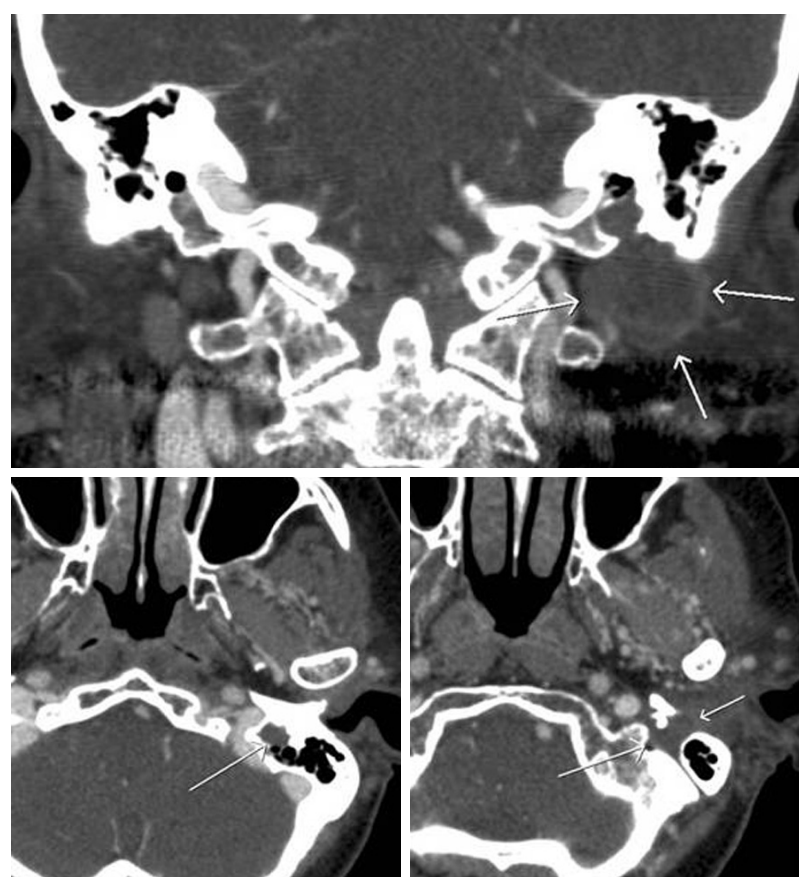

Fig. 1. Contrast enhanced temporal bone CT findings of the mass. A solid, enhancing mass (arrows) at the parotid gland extended into distal mastoid portion of the facial canal. The size of the mass was measured $3 \mathrm{~cm}$ at its largest portion.
으로 견인하여 측두골 외측의 종양을 절제하였다. 중등도 의 유착이 있었으며, 이하선과 흉쇄유돌근 사이를 박리하 는 도중 피막이 파열되어 회백색의 내용물이 유출되었다. 종양을 위쪽으로 따라가면서 측두골 내측 부분을 박리하였 다. 안면신경관 부분의 회백색 종양은 경유돌공을 향하여 신경관을 확장시키면서 측두골 외측 부분의 종양과 연결되 어 있었다. 안면신경 수직분절의 근위부에서 종양을 절제해 내었으며, 근위부에서 시행한 동결절편조직검사에서는 신경 조직과 함께 양성 방추형 세포들이 관찰되었다. 수술 부위 는 단순 봉합하였으며 환자는 수술 후 7일째 특별한 문제 없이 퇴원하였다.

최종 병리조직검사 결과에서는 수술 전 진단과는 달리 양 성 다형성선종으로 보고되었으며, 여러 층의 근상피세포 (myoepithelial cell)가 내층 도관세포를 둘러싸고 있는 관 상 구조들이 방추세포가 포함되어 있는 점액양 기질 내에 혼합되어 있는 전형적인 모습을 보였다(Fig. 3). 다형성선종 에서 흔히 관찰되는 소견으로서 피막으로 침투하는 양상을 일부에서 관찰할 수 있었으며, 수술 시 피막의 손상이 있기 는 하였으나 절제 변연의 직접적인 종양 침범은 없었다. 수 술 후 12 개월까지의 추적관찰에서 안면신경마비의 변화는 없었으며 12 개월 후 시행한 측두골 전산화단층촬영상 재발 의 소견은 보이지 않은 상태로 경과관찰 중이다.

\section{고 찰}

안면신경마비의 가장 흔한 원인은 특발성 안면신경마비로 전체의 $70 \%$ 이상을 차지하며) 측두골 골절이 두 번째로 흔 하고, 종양에 의한 경우는 전체의 약 $5 \%$ 정도를 차지한다. ${ }^{1)}$ 안면신경을 침범하는 종양 중 약 $5 \%$ 에서만 급성 안면신경 마비가 생기는데, 대부분 서서히 진행하며 종종 안면 연축 이 선행하기도 한다. 다른 뇌신경 마비의 동반, 오래 지속되 거나 편측에 반복되는 마비, 단독 신경분지의 위약, 통증, 경부나 이하선의 종양, 악성종양의 기왕력은 종양성 병변에

Fig. 2. Magnetic resonance imaging of the mass. T1-weighted axia image shows a well-marginated, hypointense mass between the left parotid gland and the mastoid tip (A). The mass is well enhanced on postcontrast T1-weighted image (B) and hyperinetnse on T2-weighted image (C).
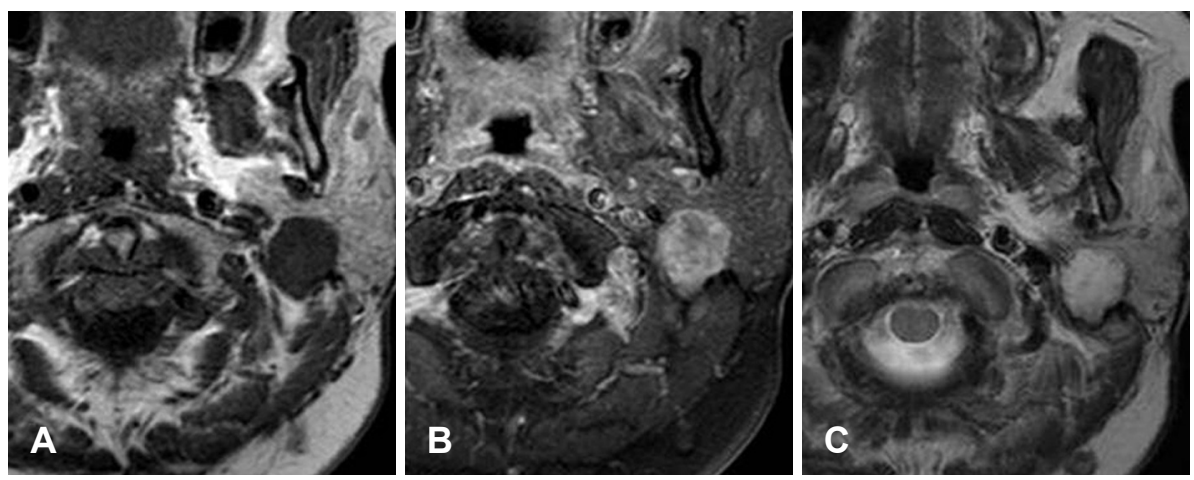

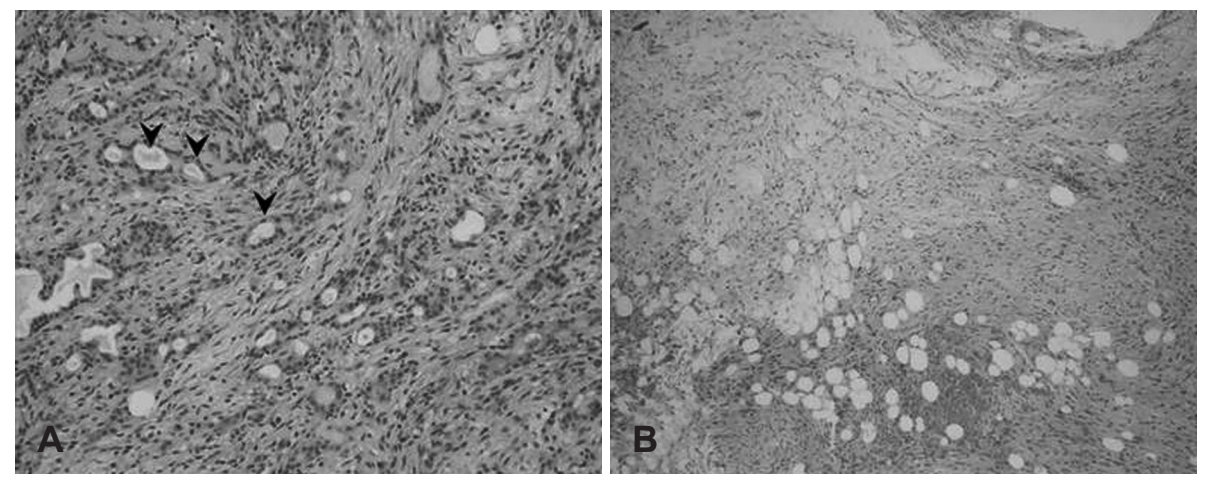

Fig. 3. Pathologic findings of pleomorphic adenoma. Basic cytoarchitectural features diagnostic of this tumor type (A). Tubules are lined by inner layer of ductal cells and an outer layer of modified myoepithelial cells of variable thickness (arrowheads). Myoeithelial cells disperse into a myxoid matrix $(\mathrm{H} \& \mathrm{E}, \times 200)$. Extracellular stroma is one of the defining components of pleomorphic adenoma (B). Benign spindle cells were noted in abundant myxoid stroma admixed with mature adipose tissue $(\mathrm{H} \& \mathrm{E}, \times 100)$.

의한 안면신경마비를 시사하는 소견이다. ${ }^{3)}$

종양에 의한 안면신경마비는 일차적으로 안면신경에서 직접 발생한 경우와 주위 조직에서 발생한 종양이 이차적으 로 안면신경 기능의 장애를 초래하는 경우로 나눌 수 있다. 안면신경에 발생하는 가장 흔한 종양은 안면신경종과 혈관 종으로 수막종, 선천성 진주종, 사구종과 함께 두개 내 부 분의 안면신경을 침범하여 안면신경마비를 일으키는 주된 원인이다. 흔하지는 않지만 유방암이나 폐암의 전이성 종양 이 측두골에 발생하여 안면신경마비를 초래할 수 있으며, 마찬가지로 이하선 종양이나 두경부 암종이 안면신경마비 를 일으킬 수 있다.

신경의 침범은 측두골의 외부 혹은 안면신경관을 따라 침 범한 종양에 의해 측두골의 내부에서 발생할 수 있는데, 신 경원성 종양에 의한 안면신경마비의 경우 주로 측두골 내부 에서 발생한다. 이하선과 두경부 악성종양의 경우, 측두골 외부의 신경을 침범하는 것은 잘 알려져 있지만, 종양이 신 경주변(perineural or extraneural)을 따라 측두골 내부 로 침범하는 경우는 비교적 드물며 현재까지 자세히 보고되 고 있지 않다. ${ }^{2)}$ Parker와 Harnsberger ${ }^{7)}$ 는 종양이 신경을 따라 침범하여 안면신경마비를 동반한 경우를 이하선 선양 낭성암종에서 5예, 피부와 구강에서 발생한 편평상피암종에 서 2예 보고하였으며, 수직 분절이 가장 흔히 영향을 받는 부분이었다. Jackson 등)도 이하선의 악성종양이 안면신경 을 따라 진행하여 경유돌공을 통해 유돌 분절을 침범한 1 예를 보고하였다.

신경에서 발생한 종양이 아닌 경우, 안면신경마비는 대부 분 악성 종양에서 보고된 것으로 신경마비의 동반은 악성을 시사하는 소견으로 여겨진다. ${ }^{2}$ 하지만 매우 드물게 양성 이 하선 종양에 이차적으로 발생하는 안면신경마비도 보고되 고 있다. 안면신경을 동반한 11예의 양성 이하선 종양에 대 한 보고가 있었으며, 이 중 2 예가 이하선에서 역행성으로
진행하여 측두골까지 침범된 경우였다. ${ }^{5)}$ Selesnick와 Patwardhan)은 비신경원성 종양이 안면신경을 따라 측두골 내까지 침범한 6 예를 보고하였는데 5 예는 악성이었다. 나머 지 1 예만이 이하선의 양성 다형성선종을 가진 35 세 환자로 1년 동안의 간헐적 이명, 현훈, 귀 주변의 저린감, 그리고 동 측 안면 표정근육의 위약을 호소하였으며, CT와 MRI에서 이하선 심엽의 종양이 유돌공을 통하여 안면신경관을 따라 후반고리관 근처까지 침범한 것이 발견되어, 유양동절제술 후 종양을 안면신경으로부터 박리해 제거하였고 수술 후 안 면신경 기능을 회복하였다고 하였다. ${ }^{2)}$ 보고된 증례에서와 달리 본 예에서는 안면신경 기능을 회복시킬 수 없었는데, 이는 수술 전 안면신경종을 의심하여 종양의 절제를 위해서 안면신경의 희생이 불가피하고, 6 년간 완전마비에 가까운 안면마비를 가지고 있었기 때문에 신경이식을 통해 재건을 한다 하더라도 기능의 회복은 불가능하다고 판단하여 이러 한 시도를 하지 않았기 때문이다.

전술하였듯이 신경 외부에서 발생한 종양이 안면신경마 비를 일으키는 경우에는 악성 종양을 의심해야 한다. 본 예 에서 저자들이 악성 종양의 가능성을 크게 고려하지 않았 던 이유는 첫째, 환자의 안면신경마비가 6년 정도로 오래되 었음에도 불구하고 종물의 크기가 외부에서 잘 촉지되지 않 을 정도로 유병기간에 비해 비교적 작은 크기였고, 빠른 성 장이나 피부의 궤양 등의 악성을 시사할 만한 다른 소견이 없었으며, 둘째, 영상학적 검사에서 안면신경 경로에 발생 한 경계가 뚜렷한 종양으로 신경원성 종양에 적합한 소견을 보였기 때문이다. 다행히 최종 병리조직검사 결과가 양성이 었지만 술 전 세침흡입검사를 시행하였다면 좀 더 정확한 정보를 가지고 수술을 진행할 수 있었을 것이다. 다형성선 종의 일차 치료는 수술적 절제로 이 환자에서 역시 완전 절 제로서 충분한 치료가 이루어졌다고 생각되었으며, 술 후 방사선 치료는 재발성 다형선종에서 술 후 절제연이 불분명 
하거나 종양세포의 파종의 의심되는 경우 시행하며 이 환자 에서는 적응이 되지 않을 것으로 판단되었다.

안면신경에서 직접 발생하지 않은 종양이 이차적으로 안 면신경마비를 일으키는 기전은 신경주위로 직접 침범하는 것(perineural invasion)과 신경이 압박되거나 신장되어 일어나는 것으로 설명할 수 있다. ${ }^{2)}$ 신경의 직접침범은 대부 분 이하선을 포함한 두경부의 악성 종양에서 관찰되는 것이 다. 특히 선양낭성암종은 신경을 따라 퍼지는 특징을 가지 고 있어, $50 \%$ 이상의 환자에서 신경침범을 발견할 수 있 다. 지금까지 보고된 양성 종양의 경우, 비록 신경 주행을 따라 두개 내까지 침범한 경우가 있긴 하였지만 실제로 신경 자체를 침범한 경우는 한 예도 없었다. 이러 경우 안면신경 마비는 종양에 의해 신경이 눌리거나 신장되어 발생한 것으 로 설명할 수 있다. 본 증례 역시 악성이 아닌 양성 다형성선 종으로 판명되었으며, 따라서 안면신경마비도 종양에 의한 직접 침범이기보다는 측두골 내부로 침범한 종양에 의한 골 관 내에서의 신경 압박이 그 원인이라고 할 수 있을 것이다.

본 증례는 양성 이하선 종양이 안면신경을 따라 측두골
내로 침범하여 안면신경마비를 일으킨 예로, 이하선 내 안 면신경초종이 의심되는 경우 배제해야 할 진단 중 하나로 염두에 두어야 할 것으로 생각된다.

\section{REFERENCES}

1) May M, Schaitkin BM. The facial nerve. $2^{\text {nd }}$ ed. New York, NY: Th ieme Medical Publishers;2000. p.393-408.

2) Selesnick SH, Burt BM. Regional spread of nonneurogenic tumors to the skull base via the facial nerve. Otol Neurotol 2003;24(2):326-33.

3) Jackler RK, Driscoll CLW. Tumors of the ear and temporal bone. Philadelphia: Lippincott Williams \& Wilkins;2000.

4) Jackson CG, Glasscock ME 3rd, Hughes G, Sismanis A. Facial paralysis of neoplastic origin: diagnosis and management. Laryngoscope 1980;90(10 Pt 1):1581-95.

5) Blevins NH, Jackler RK, Kaplan MJ, Boles R. Facial paralysis due to benign parotid tumors. Arch Otolaryngol Head Neck Surg 1992; 118(4):427-30.

6) Selesnick SH, Patwardhan A. Acute facial paralysis: evaluation and early management. Am J Otolaryngol 1994;15(6):387-408.

7) Parker GD, Harnsberger HR. Clinical-radiologic issues in perineural tumor spread of malignant diseases of the extracranial head and neck. Radiographics 1991;11(3):383-99.

8) Barrett AW, Speight PM. Perineural invasion in adenoid cystic carcinoma of the salivary glands: a valid prognostic indicator? Oral Oncol 2009;45(11):936-40. 